\title{
Determining Lethal Doses of Boron in Japanese Quails (Coturnix coturnix japonica) Diets
}

\author{
Waleed Khalid A. AL - Hayani \\ Animal Production Dep. / College of Agriculture / University Of Baghdad
}

\begin{abstract}
This study carried out in animal field in the Department of animal production /Faculty of Agriculture /University of Baghdad, Al Gadria Campus. 80 Japanese quail divided into four parameters used in this study. These quails are treated with boron $(B)$ in the diets (boric acid $16 \% \mathrm{~B}$ ) with concentration 0, 50, 75, $100 \mathrm{mg}$ $\mathrm{kg}$. diets for 120 hours. the following characteristics are examined: changes in the rate of body weight $(B L)$, concentrate of hemoglobin $(\mathrm{Hb})$, hematocrit (PCV\%), and the ratio of heterophile to Lymphocyte (H/L ratio).

The results indicated that the high levels of $B$ led to a Significant decrease in $B L$ and significantly increased in hematocrit PCV\% with significant decrease in $\mathrm{Hb}$, and increasing in the $\mathrm{H} / \mathrm{L}$ ratio. The anatomy of birds showed that there are gross lesions in each of the liver and kidneys.

The current study concludes that the use of $B$ in high concentrations in the fodder of quails led to the toxic effects that lead to the physiological deterioration of birds but it was not fatal.
\end{abstract}

Keyword; Boron, Lethal Doses, Japanese Quails.

\section{Introduction}

It features a Japanese quail rate of the rapid growth and more popular for producing eggs. These birds are highly resistance to the diseases and they suffer from the same diseases that afflict the chicken, but its resistance is higher than the chicken for disease resistance (Randall and Bolla, 2008). The high production and the rapid growth accompanied with lower body immunity and increase the chances of infection diseases (Jatau at. al., 2014). The increased production and the rapid of growth requires an increase to mineral elements are rare, and the lack of one or more of these elements lead to clear deterioration in the health of the birds (Abbaspour at. al., 2014).

used metal components in to address some of these problems, the fodder elements of scarce mineral important in modern nutrition poultry culling, that it is necessary for growth and food representation and sustainability of the vital activities of the stimulation of enzymes (Swiatkiewicz at. al., 2014), as well as the roles of antioxidants working to protect tissues from damage (Ibrahim, 2013). In addition to their roles and immune task (Yatoo at. al., 2013), B is one of the most important of these elements, that was used in the intimate relations fodder (Lavinia at. al., 2014). And of the elements of scarce mineral non-metallic, occupies IIIA of the periodic table (Mendeleev table). Its atomic number is 5 , standard atomic 10.81, and it has two peers in nature, B10 and B11 (Who,1998 a).

Gay - Lussac and Sir Humphry Davey was isolating B laboratory in 1808 through heating carbon dioxide baron with the element of potassium permanganate (Who, 1998 b; Kilie et al, 2009).

B plays a regulatory role in metabolism of mineral elements such as calcium (Ca), phosphorus $(\mathrm{P})$, magnesium $(\mathrm{Mg})$ and vitamin $\mathrm{D}$, through its important role in the organization of the work of the parathyroid glands, thus building bones (Nielsen Survey, 1990; Devirian and Volpe, 2003; Bozkurt and Kucukyilmaz, 2015). Hunt at. al. (1983) state that the availability of B, Ca or B, Mg in intimate ration of broilers had led to improved growth to increase interest rates of $\mathrm{Ca}, \mathrm{Mg}$ and as well as the roles of $\mathrm{B}$ functions. With regard to the impact of $\mathrm{B}$ in metabolism of $\mathrm{P}$ and $\mathrm{Ca}$ that happen through its impact on the enzymatic systems or hormonal contraceptives (Hunt at. al., 1983), through organization of the work of the parathyroid glands, to work to reduce the excessive activity (hyperparathyroidism), and then to organize $\mathrm{Ca}$ levels of $\mathrm{P}$ in the body (Fisher, 2016). It also operates the $B$ organization of the work of the Thyroxine hormone $\left(T_{4}\right)$ and increases its concentrations in the blood (Gregory and Kelly, 1997). As Nielsen and Penland (1999) referred to the addition of B led to increased concentrations of the hormonal T3 and T4 in serum of blood and increase the amount added lead to high concentration of hormones itself, but it did not specify the exact mechanism which explain the relationship between the increase in the concentration of thyroid hormones with increased the quantity of B. The Armstrong and Spears (2003) state that the reducing of the concentration of B will lead to the reduction of the focus of the thyroid hormones in the blood vaccine pigs prone to the shortage (Cinar at. al., 2015).

Hegsted at. al. (1991) noticed that the shortage of B lead to imbalance contains all of $\mathrm{Ca}, \mathrm{P}, \mathrm{Mg}$ in blood plasma of mice. It also leads to a lack of vitamin $\mathrm{D}_{3}$, and the decline in the focus of the triglycerides concentration of triglycerides and increasing in the concentration of pyruvic acid in plasma (Volpe at. al., 1993), the lack of B lead to increased concentration of the insulin over the levels required to concentrate glucose in the 
blood in presence or absence of vitamin $\mathrm{D}_{3}$. In other words, it leads to imbalance in birds' energy metabolism particularly chicks with an imbalance in the metabolism of energy (Bakken and Hunt, 2003). The time has proved that the lack of B lead to delay in the growth of the overall inflation and spleen (Nielsen survey at. al., 1988) and is therefore a B has an important role in growth and the preservation of the functions of the body (Kabu and Akosman, 2013).

Proved that the B strengthen the functions of the body's vital when using it in safe concentrations (Moss and Nagpal, 2003). Moreover, all boron's vital roles mentioned above, the high concentrations of B will lead to some disorders, Korolev et al. (1989) notice that the addition of B in concentration of $250 \mathrm{mg} / \mathrm{liter}$ of water led to changes in tissues of the thyroid Gland, Puls (1994) also states that the deadly dose 50 Lethal Dose for chicks in the age of 1 day equal $3000 \mathrm{mg}$ of boric acid/Kg of body weight district. While in ducks, he noticed that $1000 \mathrm{mg}$ of $\mathrm{B} / \mathrm{kg}$ of diets led to destruction of duck's chicks during the first week of birth it also reduce of hatched chickens (plus, 1994), either dose $300 \mathrm{mg} \mathrm{B} \mathrm{/} \mathrm{kg}$ of diet had no impact on the proportion of hatching eggs. For hatched chicken in the age of one day, the amount of deadly chicks is about $2.95 \mathrm{~g} / \mathrm{kg}$, the adding of this quantity is toxic for chickens( Sander et al 1991).

Al - Hamdani (2016) states that adding B to fodder in concentration of $45 \mathrm{mg} / \mathrm{kg}$ fodder led to a significant deterioration in the rate of body ratio, feed conversion ratio, dressing percentage and the relative weight of cuts accompanied by the deterioration in many physiological characteristics.

\section{Hypothesis of the Study}

Despite the multiplicity of the studies but they did not address any study on the effect of high concentrations in Japanese quail and identify the toxicity of B. Therefore, this study was conduct to determine lethel doses of $\mathrm{B}$ and diagnosis of the negative effects of the high concentration of $\mathrm{B}$ in fodders.

\section{Materials and Methods}

This study is conducted in the animal house, Department of animal production / College of agriculture, the University of Baghdad, Al Gadria campus, for the period from 07/12/2016 to 13/12/2016. 80 Japanese quail used in this study are divided into four parameters, for each transaction 20 birds (10 males, 10 females), numbered with metal numbers and put in plastic cages $(75 \times 100 \mathrm{~cm})$ provided fodder and water in freeway (adlibitum), having provided diets with $3150 \mathrm{Kcal} / \mathrm{kg}$, and $22 \%$ Crude protein, after control the temperature $\left(24^{\circ} \mathrm{C}\right)$ and ventilation of the house.

Boric acid $(16 \%$ B) is used which equipped from Sinopharm Company Chemical Reagent Co., Ltd. as a source of $\mathrm{B}$, it is added to the diets according to the following:

$\mathrm{B}_{0}$ : treatment of the control of the non-add.

$\mathrm{B}_{50}$ : Add $\mathrm{B}$ in concentration of $50 \mathrm{mg} / \mathrm{kg}$ diet.

$\mathrm{B}_{75}$ : Add $\mathrm{B}$ in concentration of $75 \mathrm{mg} / \mathrm{kg}$ diet.

$\mathrm{B}_{100}$ : Add B in concentration of $100 \mathrm{mg} / \mathrm{kg}$ diet .

All birds are weighed before treatment with B-loaded materials, after 120 hours of treatment include Bloaded materials., record the pre and post of the living weight birds and changes in the rate of live body weight (BW) (the difference between the pre and post, BL), then the collection of blood from the jugular vein (Campbell, 1995; Campbell and Ellis,2007), by using an injection of $3 \mathrm{ml}$ with a needle measuring 25, then measure PCV\% (Archer, 1965), while the Hb is measured (Varley at. al., 1980) in order to calculate H/L ratio. It also calculate the concentration of $\mathrm{B}, \mathrm{Ca}$ and phosphor in the serum of the blood for two periods (before treatment) and after 120 hours of treatment. Then the birds are taking their bodies parts (anatomy) to note the damages that occurred for each of the liver and kidneys, (Saif, 2003)

Data of this experiment analyzed in the design of the full random Complete Randomize Design (CRD), to study the impact of various transactions in the thoughtful attributes. The superintendent's moral differences between the averages by Duncan's test (1955). Apply the statistical program SPSS (2010) in the statistical analysis.

\section{Results and Discussion}

Table 1 indicates the presence of Significant decrease $(\mathrm{p}<0.01)$ in BW of Japanese quail which treated include $\mathrm{B}$ - loaded materials $\left(\mathrm{B}_{50}, \mathrm{~B}_{75}, \mathrm{~B}_{100}\right)$, compared with the treatment of control $\left(\mathrm{B}_{0}\right)$. After eating diets that contains $\mathrm{B}$, there is reducing 10.77 and 17.39 and 23.99 grams of transactions $\mathrm{B}_{50}, \mathrm{~B}_{75}, \mathrm{~B}_{100}$ respectively, while the $\mathrm{BW}$ for the treatment of control by $12.26 \mathrm{~g}$ during $120 \mathrm{~h}$ of the pilot phase. It also notes that the use of $\mathrm{B}$ in concentration of $100 \mathrm{mg} / \mathrm{kg}\left(\mathrm{B}_{100}\right)$ led to Significant decrease $(\mathrm{p}<0.01)$ in feed intake $(\mathrm{FI})$ compared by $\mathrm{B}_{0}, \mathrm{~B}_{50}$ and $\mathrm{B}_{75}, \mathrm{~B}_{50}$ and $\mathrm{B}_{75}$ are also recorded compared $\mathrm{B}_{0}$, and notes the Significant differences among $\mathrm{B}_{50}$ and $\mathrm{B}_{75}$, as well as between $\mathrm{B}_{75}$ and $\mathrm{B}_{100}$. 
Table 2 indicates that there are no significant differences in the PCV\%, $\mathrm{Hb}$ and $\mathrm{H} / \mathrm{L}$ before treating birds with high concentrations of $\mathrm{B}$, while from the same table it noted that $\mathrm{B}_{50}$ and $\mathrm{B}_{100}$ recorded significant increase $(\mathrm{p}<0.05)$ in the PCV\% after treatment with $\mathrm{B}$ comparing with the $\mathrm{B}_{0}, \mathrm{~B}_{75}$ have been noted between them any moral differentials, at the same time it is noticed that adding $\mathrm{B}$ to the diet in concentrations 50, 75, 100 $\mathrm{mg} / \mathrm{kg}$ led to significant decrease in $\mathrm{Hb}$ compared with control treatment $\left(\mathrm{B}_{0}\right)$. From the same table, it is noted that the high concentration of $B$ in the fodder led to Significant increase in H/L ratio, of $B_{100}$ compared with other experimental treatment, it also noticed that Significant increase to $\mathrm{B}_{75}$ compared with $\mathrm{B}_{0}$, finally it is not noticed any significant differences between $\mathrm{B}_{50}$ and $\mathrm{B}_{75}$, as well as between $\mathrm{B}_{0}$ and $\mathrm{B}_{50}$.

Anatomy of birds shows that there are lesions gross in each of the liver and kidney and, as noted from table 3 Presence of significant differences between the transactions in addition B high concentrations compared to the treatment of control, each of the kidneys $(\mathrm{p}<0.01)$ and liver $(\mathrm{p}<0.05)$, in the percentage of lesions gross.

Despite of there is no any records of destructions as a result of adding high concentrations of $\mathrm{B}$ to the fodder but the negative side effects of high concentration showed that lowest reducing in BW (table 2), which reached in $23.99 \mathrm{~g}$ in $100 \mathrm{mg} / \mathrm{kg}$, this may be due to the increasing of B in the diet, had adversely affected the thyroid gland and its hormones, $\mathrm{T}_{4}, \mathrm{~T}_{3}$ (Last, 2012)

Moreover, $\mathrm{B}$ has a role in organizing the relationship between $\mathrm{Ca}$ and $\mathrm{Mg}$ inside cells, in addition, the increasing of B concentration plays a role in extraction of mineral elements of cells and disruption of the roles of plasma membrane by controlling on the thyroid gland (Jones et al, 2011).

The decline in the activity of the thyroid gland and its hormones led to the reduction of the metabolic rates in the body, accompanied by reduction in the activity of growth hormone and IGF-II. Thus, the appetite for fodder will be reduced (table 1), or may be due to a reason that the B plays a role in increasing the activity of thyroid hormones in the blood as previously mentioned and the increasing of B plays a role in increasing their concentration, therefore many cases of destruction of the tissues of the body occurred. Which reflected in the decline in the BW (sturkie, 2000). The low level of $\mathrm{Hb}$ and PCV\% to B parameters in high concentrations (table 2) which confirms the stress that birds infected as a result of food shortages as B contributes with copper $(\mathrm{Cu})$ in organizing iron $(\mathrm{Fe})$ absorption, and any increasing in $\mathrm{B}$ levels will led to the accumulation of $\mathrm{Cu}$ and $\mathrm{Fe}$ in the liver and prevent the process of building blood cells (Chauvel et al, 2006k; Kaya, 2012), while the significant increasing in the $\mathrm{H} / \mathrm{L}$ ratio, is the largest signals on the strain of birds caused by the increasing in the levels of hormone corticosterone (Al - Daraji et. al., 2012).

Gross lesions have been observed in each of the kidneys and the liver, confirms that the unrest in the metabolism of $\mathrm{Fe}, \mathrm{Cu}, \mathrm{Ca}$ and $\mathrm{Mg}$ (Last, 2012), due to the $\mathrm{B}$ role in organizing the thyroid and parathyroid glands (Jones et. Al., 2011), which is one of the clinical signs of unrest metabolism operations in the body.

\section{Conclusion and Recommendations}

As all mentioned above, this study concludes that the concentrations used in this study were not fatal, but these concentrations led to reduction of birds healthy and their functions through lowest reduction of body weight, particularly in concentration $100 \mathrm{mg} / \mathrm{kg}$.

Table 1. Effect of adding high concentrations of Boron (B) to the diet in live body weight (BW), changes in body weight (BL) and feed intake (FI) for Japanese quails

\begin{tabular}{|c|c|c|c|c|}
\hline \multirow[b]{2}{*}{ TRT } & \multicolumn{2}{|c|}{ body weight (g / bird) } & \multirow[b]{2}{*}{$\begin{array}{l}\text { Changes in body } \\
\text { weight (g / bird) }\end{array}$} & \multirow{2}{*}{$\begin{array}{l}\text { Feed intake } \\
\text { (g/ bird) }\end{array}$} \\
\hline & $\begin{array}{c}\text { Initial weight } \\
(35 \mathrm{D} \text { old })\end{array}$ & $\begin{array}{c}\text { Weight after } 120 \mathrm{H} \\
(40 \mathrm{D} \text { old })\end{array}$ & & \\
\hline $\mathbf{B}_{0}$ & $140.25 \pm 4.44$ & $152.51 \pm 4.16 \quad \mathrm{~A}$ & $12.26 \pm 5.92$ & $110.33 \pm 2.73$ \\
\hline $\mathbf{B}_{50}$ & $140.77 \pm 2.69$ & $130.00 \pm 2.97$ & $-10.77 \pm 4.65$ & $78.00 \pm 9.17$ \\
\hline $\mathbf{B}_{75}$ & $140.40 \pm 1.08$ & $123.01 \pm 6.14$ & $-17.39 \pm 5.11$ & $66.67 \pm 7.51$ \\
\hline $\mathbf{B}_{100}$ & $140.66 \pm 1.06$ & $116.67 \pm 4.41$ & $-23.99 \pm 5.06$ & $52.82 \pm 6.68$ \\
\hline Sig. & N.S & 0.01 & 0.01 & 0.01 \\
\hline
\end{tabular}

$B_{0}, B_{50}, B_{75}, B_{100}$ : adding Boron (B) to the diet in concentrations 0, 50, 75, $100 \mathrm{mg} / \mathrm{kg}$ respectively. N.S: Not significant.

$\mathrm{A}, \mathrm{B}, \mathrm{C}$ : Means within a Colum lacking a common superscript differ significantly. 
Table 2. Effect of adding high concentrations of Boron (B) to the diet in Hematocrit (PCV \%),

Hemoglobin $(\mathrm{Hb})$ and Heterophile/Lymphocyte ratio (H/L ratio) for the Japanese quails

\begin{tabular}{|c|c|c|c|c|c|c|}
\hline \multirow{2}{*}{ TRT } & \multicolumn{2}{|c|}{ Hematocrit (PCV\%) } & \multicolumn{2}{|c|}{ Hemoglobin $(\mathrm{Hb})(\mathrm{g} / 100 \mathrm{ml})$} & \multicolumn{2}{|c|}{$\begin{array}{l}\text { Heterophile/Lymphocyte } \\
\text { ratio }\end{array}$} \\
\hline & Before & $\begin{array}{l}\text { after } 120 \mathrm{H} \\
(40 \mathrm{D} \mathrm{old})\end{array}$ & Before & $\begin{array}{l}\text { after } 120 \mathrm{H} \\
(40 \mathrm{D} \text { old })\end{array}$ & Before & $\begin{array}{c}\text { after } 120 \mathrm{H} \\
(40 \mathrm{D} \text { old })\end{array}$ \\
\hline $\mathbf{B}_{0}$ & $45.17 \pm 2.62$ & $41.17 \pm 1.88^{\mathrm{B}}$ & $14.18 \pm 1.08$ & $15.28 \pm 1.65$ & $0.37 \pm 0.02$ & $0.34 \pm 0.03$ \\
\hline $\mathbf{B}_{50}$ & $45.67 \pm 1.86$ & $49.00 \pm 1.53^{\mathrm{A}}$ & $14.23 \pm 0.36$ & $9.27 \pm 1.25^{\mathrm{B}}$ & $0.41 \pm 0.02$ & $0.46 \pm 0.06$ \\
\hline $\mathbf{B}_{75}$ & $44.33 \pm 2.03$ & $37.67 \pm 3.76^{\mathrm{B}}$ & $12.59 \pm 0.55$ & $8.66^{ \pm 1.36^{\mathrm{B}}}$ & $0.40 \pm 0.07$ & $0.54 \pm 0.06$ \\
\hline$\overline{\mathbf{B}_{100}}$ & $47.83 \pm 2.46$ & $51.00 \pm 1.53^{\mathrm{A}}$ & $14.76 \pm 0.81$ & $9.91 \pm 1.64^{\mathrm{B}}$ & $0.39 \pm 0.08$ & $0.73 \pm 0.03$ \\
\hline Sig. & N.S & 0.05 & N.S & 0.05 & N. $S$ & 0.05 \\
\hline
\end{tabular}

$B_{0}, B_{50}, B_{75}, B_{100}$ : adding Boron (B) to the diet in concentrations 0, 50, 75, $100 \mathrm{mg} / \mathrm{kg}$ respectively. N.S: Not significant.

A, B, C : Means within a Colum lacking a common superscript differ significantly.

Table 2. Effect of adding high concentrations of Boron (B) to the diet in lesions gross for the Japanese quails

\begin{tabular}{|c|rr|rr|}
\hline \multirow{2}{*}{ TRT } & \multicolumn{4}{|c|}{ lesions gross (\%) } \\
\cline { 2 - 5 } & Kidney & & Liver & \\
\hline $\mathbf{B}_{\mathbf{0}}$ & $0.00 \pm 0.00^{\mathrm{B}}$ & $0.00 \pm 0.00$ & $\mathrm{~B}$ \\
\hline $\mathbf{B}_{\mathbf{5 0}}$ & $50.00 \pm 1.89^{\mathrm{A}}$ & $25.00 \pm 1.64$ & $\mathrm{~A}$ \\
\hline $\mathbf{B}_{\mathbf{7 5}}$ & $75.00 \pm 1.64$ & $\mathrm{~A}$ & $25.00 \pm 1.64$ & $\mathrm{~A}$ \\
\hline $\mathbf{B}_{\mathbf{1 0 0}}$ & $87.50 \pm 1.25$ & $\mathrm{~A}$ & $37.50 \pm 1.83$ & $\mathrm{~A}$ \\
\hline Sig. & 0.01 & & 0.05 & \\
\hline
\end{tabular}

$B_{0}, B_{50}, B_{75}, B_{100}$ : adding Boron (B) to the diet in concentrations 0, 50,75, $100 \mathrm{mg} / \mathrm{kg}$ respectively. $\mathrm{A}, \mathrm{B}, \mathrm{C}$ : Means within a Colum lacking a common superscript differ significantly.

\section{References}

[1]. Abbaspour, N., R. Hurrell and R. Kelishadi. 2014. Review on iron and its importance for human health. J. Res. Med. Sci. 19: $164-$ 174.

[2]. $\quad \mathrm{Al}-$ Daraji, H. J., W. K. A. Al - Hayani, A. S. Al - Hassani. 2012. Avian Hematology. 1st ed. Ministry of Higher Education and Scientific Research, University of Baghdad. College of Agriculture.

[3]. $\mathrm{Al}$ - Hamdani, Sh. A. J. 2016. Effect of adding different levels of boricacid as a source of boron to the diet on productive and some physiological traits of broiler chickens. Master Thesis. College of Agriculture, University of Baghdad.

[4]. $\quad \mathrm{Al}$ - Zubaidi, S. S. A. 1986. Poultry management. 1st ed. College of Agriculture - University of Basra.

[5]. Archer, R. K. 1965. Hematological Techniques for Use on Animals. Blackwell Scientific Publications, Oxford.

[6]. Armstrong, T.A. and J.W. Spears,. 2003. Effect of boron supplementation of pig diets on the production of tumor necrosis factor and interferon. J. of Anim. Sci. 81: $2552-2561$.

[7]. Bakken, N.A., and C. D. Hunt.2003. Dietary boron decreases peak pancreatic in situ insulin release in chicks and plasma insulin concentrations in rats regardless of vitamin D or magnesium status. J. Nutr. 133: $3577-3583$.

[8]. Bozkurt, M. and K. Kucukyilmaz. 2015. An evaluation on the potential role of boron in poultry nutrition.Part I: Production performance. World's Poultry Sci. J. 71: $327-338$

[9]. Campbell, T. W. 1995. Avian hematology and Cytology.Iowa State University Press, Ames, Iowa.

[10]. Campbell, T. W. and C. K. Ellis. 2007. Avian and Exotic Animal Hematology and Cytology. 3rd ed. Blackwell Publishing Professional, State Avenue, Ames, Iowa50014, USA.

[11]. Chauvel, J. 2002. Hand book of copper compounds and applications, Mercel Dekker in. publisher, New York, USA. 177 - 202.

[12]. Cinar, M., K. Kucukyilmaz, M. Bozkurt, A. U. Catli, E. Bintas, H. Aksit, R. Konak, C. Yamaner, and K. Seyrek. 2015. Effects of dietary boron and phytase supplementation on growth performance and mineral profile of broiler chickens fed on diets adequate or deficient in calcium and phosphorus. Br. Poultry Sci. 56 (5): 576 - 589.

[13]. Devirian, T.A. and S. L. Volpe. 2003. The physiological effects of dietary boron. Crit .Rev. Food .Sci .and. Nutrit.43:219 - 231.

[14]. Duncan, D.B. 1955. Multiple range and Multiple F test. Biometrics. 11: 1 - 42.

[15]. Fisher, H. W. 2016. The Physiological Impact of Boron. http://www.pdfsea.net/result/boron-element/p/. Data of access: 18/11/2016

[16]. Gregory, S. and N. D. Kelly. 1997. Boron: A Review of its Nutritional Interactions and Therapeutic Uses .Alternative .Medicine Review. $2: 48-56$

[17]. Hegsted, M., M. J. Keenan, F. Siver and P. Wozniak. 1991. Effect of boron on vitamin D deficient rats. Biol Trace Elem Res 28: $243-256$.

[18]. Hunt, C.D., T. Shuler and F. Nielsen. 1983. Effect of boron on growth and mineral metabolism. In: Anke, M., Baluman, W., Braunlich, H., Bruckner, C. (eds) 4 Spurenelement- symposium. Friedrich- Schiller University, Jena, Germany.149-155.

[19]. Ibrahim, N.L. 2013. Study of Serum Copper and Iron in Children with Chronic Liver Diseases. AnatPhysiol 4:130.

[20]. Jatau, I.D., A.N. Odika, M. Thlama, A.M. Talba, M. Bisalla and I.W. Musa.2014. Response of 2 breeds of broiler chicks to experimental infection with low dose of Eimeria tenell asporulated oocysts. Turk. J. Vet. Anim. Sci. 38: 398 - 404.

[21]. Jones, J. E., P. C. Desper, S. R. Shane and E. B. Flink. 2010. Magnesium Metabolism in Hyperthyroidism and Hypothyroidism. J. of Clinical Investigation. 45 (6): $891-900$. 
[22]. Kabu, M. and M. S. Akosman. 2013. Biological Effects of Boron. Reviews of Environmental Contamination and Toxicology. 225: $57-75$.

[23]. Kaya, A., A. Altiner and A. Ozpinar. 2006. Effect of copper deficiency on blood lipid profile and haematological parameters in broilers. J. Vet. Med. A 53: $399-404$

[24]. Kilic, A. M., O. Kilic, I. Andaç, and A. G. Celik. 2009. Boron mining in Turkey, the marketing situation and the economical importance of Boron in the World IV, International boron symposium, Eskişehir- Turkey. 15-17 Oct.

[25]. Korolev, L.U. N., L.N. Panova, A.S. Bobkova and E.G. Korovkina. 1989. Morphofunctional characteristics of the thyroid and a change in the level of thyroid hormones in the blood from the internal use of boron containing waters. Vopr. Kurortol. Fizioter. Lech. Fiz. Kult. Iss. 3: 28-31.

[26]. Kurtoglu, F., V. Kurtoglu, I.Celik, T.Kceci and M. Nizamlioglu. 2005. Effects of dietary boron supplementation on some biochemical parameters, peripheral blood lymphocyte, splenic plasma cell counts and bone characteristics of broiler chicks fed with adequate or inadequate vitamin D3 containing diet. Br. Poultry Sci. 46: 87 - 96

[27]. Last, W. 2012. The borax conspiracy. http://www.checktheevidence.com/pdf/Borax-Txt.pdf. Access of data: 1/1/2017.

[28]. Lavinia, S., D. Dna, S.D.Sandu, P.Ioan, P.Elena and S.Eliza.2014. Effects of new mineral sources for boron supplementation on meat quality in broilers. Rom. Bio.tech. L.19:9585-9596.

[29]. Moss, S. A. and N. K. Nagpal. 2003. Ambient Water Quality Guidelines for Boron. Full Report. British Columbia. Water, Air and Climate Change Branch.

[30]. Nielsen, F. H. and J. G. Penland. 1999. Boron supplementation of menopausal women affects boron metabolism and indices associated with macro mineral metabolism, hormonal status and immune function. J. of Trace Elements in Expe.Medic. 12: 251 261.

[31]. Nielsen, F. H., T. R. Shuler, T. J. Zimmerman and E. O. Uthus. 1988. Magnesium and methionine deprivation affect the response of rats to boron deprivation. Biol Trace Elem. Res. 17:91-107.

[32]. Nielsen, F.H. 1990. Studies on the relationship between boron and magnesium which possibly affects the formation and maintenance of bones.Magnes. Trace. Elem. 9: $61-69$

[33]. Puls, R. 1994. Mineral Levels in Animal Health: Diagnostic Data. 2nd ed. Sherpa International, Clearbrook, British Columbia.

[34]. Randall, M. and Bolla, G. 2008. Raising Japanese quail. Nsw Department of Primary Industries.P.P.1-5. http://www.dpi.nsw.gov.au/_data/assets/pdf_file/0005/145346/Raising-Japanese-quail.pdf.

[35]. Saif, Y. M., H. J. Barnes, A. M. Fadly, J. R. Glisson, L. R. McDougald and D. E. Swagne. 2003. Disease of Poultry, 11th ed. Iowa state press. Blackwell publishing company. USA.

[36]. Sander, J. E., L. Dufour, R. D. Wyatt, P. B. Bush and R. K. Page. 1991. Acute toxicity of boric acid and boron tissue residues after chronic exposure in broiler chickens. Avian Dis. 35:745 - 749.

[37]. SPSS. 2010. User guide statistic version, 18th ed. SPSS, statistical package for social science, user guide statistical version, 6th ed.

[38]. Squires, E.J. 2003. Applied Animal Endocrinology. CAB International. Wallingford. Oxon OX10 8DE. UK.83 - 85.

[39]. Sturkie, P. D. 2000. Avian Physiology. 5thed. New York, Heiderberg, Barlin, Springer Verlag.

[40]. Swiatkiewicz, S., A. Arczewska - Wlosek and D. Jozefiak. 2014. The efficacy of organic minerals in poultry nutrition: review and implications of recent studies. World's Poultry Sci. J. 70: $475-486$

[41]. Varley, H., A. H. Gowenlock and M. Bell. 1980. Practical Clinical Biochemistry. 5th ed. William Heinemann Medical Books Ltd., London. Sciences Symposium Dallas. 4 - 6: 23 - 27.

[42]. Volpe, S. L., L. J. Taper and S. Meacham. 1993. The relationship between boron and magnesium status and bone mineral density in the human: a review, Magnes. Res. 6: $291-296$.

[43]. WHO (World Health Organization). 1998 a. Environmental Health Criteria 204: Boron. Geneva, Switzerland: World Health Organization.

[44]. WHO (World Health Organization). 1998 b. Environmental health criteria 204: boron. International programme on chemical safety, Geneva, Switzerland.ISBN 924157204 3. 105 - 110.

[45]. Yatoo, M. I., A. Saxena, P. M. Deepa, B. P. Habeab, S. Devi, R. S. Jatav and U. Dimri. 2013. Role of Trace elements in animals: a review, Vete. World. 6 (12): $963-967$ 